\title{
Financial well-being of Malaysian college students
}

\begin{abstract}
Purpose: The purpose of this paper is to examine the relationships between personal and family backgrounds, academic ability, childhood consumer experience, financial socialization, financial literacy, and perceived financial well-being of college students.

Design/methodology/approach: Data were collected using a multi-stage sampling technique from 11 public and private universities across Malaysia and the sample consists of 2,219 college students. Structural equation modelling was utilized to test the hypotheses.

Findings: Childhood consumer experiences such as savings habits contribute to studentsô financial well-being (money saved, current financial situation, and financial management skills). Financial socialization agents, for example, through parents and religion sources could increase college studentsô financial well-being. Financial literacy was related to financial well-being. There were important differences between the Malay and Chinese ethnic groups in Malaysia.
\end{abstract}

Research limitations/implications: Overall, implications and recommendations for future research, teaching, and public policy are also provided for parents, college administrators, counselors and educators.

Originality/value: This research provides meaningful information about how various factors (childhood experience, financial socialization, and financial literacy) predict studentsô financial well-being.

Keyword: Malaysia; Universities; Students; Personal finance; Financial well-being; Financial literacy; Financial socialization; Childhood consumer experience 